\title{
EFFECTS OF EXOTIC GRASSES ON SOIL SEED BANKS IN SOUTHEASTERN ARIZONA GRASSLANDS
}

\author{
Steven P. McLaughlin ${ }^{1}$ and Janice E. Bowers ${ }^{2}$
}

\begin{abstract}
At the Appleton-Whittell Research Ranch, an ungrazed grassland preserve in southeastern Arizona, soil seed banks were sampled in June, August, and October 2002 and June 2003. Wildfire had previously burned $90 \%$ of the research ranch in May 2002. Seed density and species richness in burned native grassland (2 plots) were compared to those in burned exotic grassland ( 2 plots). Averaged over 4 sample dates, seed densities were as follows: burned native grassland, $591 \pm 243.1$ seeds $\cdot \mathrm{m}^{-2}$ and $784 \pm 334.9 \mathrm{seeds} \cdot \mathrm{m}^{-2}$; burned exotic grassland, $501 \pm 198.9 \mathrm{seeds} \cdot \mathrm{m}^{-2}$ and 196 \pm 123.8 seeds $\cdot \mathrm{m}^{-2}$. Species richness in the seed bank, also averaged over 4 sample dates, was as follows: burned native grassland, $16.3 \pm 1.7$ species $\cdot \mathrm{m}^{-2}$ and $19.5 \pm 1.0$ species $\cdot \mathrm{m}^{-2}$; burned exotic grassland, $12.0 \pm 3.4$ species $\cdot \mathrm{m}^{-2}$ and $11.06 \pm 2.5$ species $\cdot \mathrm{m}^{-2}$. The seed bank of burned exotic grassland contained significantly fewer seeds and species than that of burned native grassland. In addition, the seed bank in burned exotic grassland comprised mainly exotic grasses, whereas annual and perennial herbs, most of them native, dominated the seed bank of burned native grassland. Of the 50 species detected in soil samples, only 20 had a persistent seed bank, and only 1 of these was a native perennial bunchgrass. The preponderance of transient species means that eradication of exotic grasses must be followed by reseeding of native grasses and herbs, perhaps repeatedly, if native grassland is to replace exotic grassland.
\end{abstract}

Key words: seed density, seed longevity, species richness, alien plants, Eragrostis curvula.

In a study conducted in southeastern Arizona between 1997 and 2001, grassland dominated by an exotic bunchgrass (Eragrostis curvula var. conferta) was less diverse than grassland dominated by native bunchgrasses (McLaughlin and Bowers 2006; see also Bock et al. 1986). Specifically, $1-\mathrm{m}^{2}$ quadrats in exotic grassland supported $72 \%$ fewer species on average than quadrats in native grassland and oak savanna (McLaughlin and Bowers 2006). Suspecting that exotic grassland had been depleted of species belowground as well as aboveground, we undertook a baseline study to compare seed banks in native and exotic grasslands. Our study site was the AppletonWhittell Research Ranch, a grassland preserve in southeastern Arizona that had not been grazed by domestic livestock for more than 30 years.

A seed bank is simply the reservoir of seeds and fruits on or in the soil. Natural seed banks can be classified as long-term persistent (seed longevity $\geq 5$ years), short-term persistent $(>1$ year to $\leq 4$ years), or transient ( $\leq 1$ year; Thompson et al. 1993). Most bunchgrass species found in southeastern Arizona lack persistent seed banks (Major and Pyott 1966, Rabinowitz 1981, Hassan and West 1986, Coffin and Lauenroth 1989, Kinucan and Smeins 1992). Their seeds typically disperse in summer or autumn, and germinate during the following summer if they receive enough rain (Abbott and Roundy 2003). In the meantime, a substantial proportion are consumed by granivores (Brown et al. 1975, Pulliam and Brand 1975). Uneaten seeds that fail to germinate within a year of dispersal presumably lose viability and eventually decay (Kinucan and Smeins 1992).

Because native bunchgrass assemblages depend upon sexual reproduction to maintain their continuity, any event or disturbance that repeatedly or persistently removes the source of seeds can threaten community stability (O'Connor and Pickett 1992). During the late 1800 s, for example, a combination of heavy grazing by domestic livestock and severe drought greatly reduced native bunchgrass cover in parts of southeastern Arizona, leaving former grassland vulnerable to invasion by shrubs (Bahre 1991, McPherson and Weltzin 2000, Turner et al. 2003). In California, especially in the foothills surrounding the Central

1Office of Arid Lands Studies, University of Arizona, Tucson, AZ 85721. E-mail: spmcl@ag.arizona.edu

${ }^{2}$ U.S. Geological Survey, 1675 West Anklam Road, Tucson, AZ 85745. 
Valley, overgrazing in the 19th century depleted grasslands of native bunchgrasses, allowing exotic annual grasses to take their place (Burcham 1957, Major and Pyott 1966).

Southeastern Arizona grasslands face a similar threat from exotic grasses, particularly Eragrostis lehmanniana (Lehmann lovegrass) and E. curvula var. conferta (Boer lovegrass). These species were introduced by the Soil Conservation Service after the drought of the 1930s in an effort to prevent soil erosion and restore grass cover for the livestock industry (Crider 1945, Cox et al. 1988). They are undesirable in any landscape for which managers seek to preserve natural biodiversity. Fewer species of rodents, birds, and grasshoppers are found in stands of exotic lovegrasses than in stands of native bunchgrasses (Bock et al. 1986), and, as noted, the number of plant species is also lower (Bock et al. 1986, McLaughlin and Bowers 2006). Seeds of both E. lehmanniana and E. curvula var. conferta have a high degree of dormancy (Weaver and Jordan 1986, Voigt et al. 1996) and likely can survive in the soil for several years. Persistent seed banks enable them to maintain local dominance despite fire, drought, and treatment with herbicides (Biedenbender and Roundy 1996, Voigt et al. 1996).

One reason for determining the transience or persistence of seeds in the soil is to evaluate the potential of a community to rebound from destruction or degradation (Thompson et al. 1997). Our goal at the outset was to determine what type of seed bank remained in exotic grassland to reestablish a diverse native community should some means of reducing exotics be found. Before our initial sampling of the seed bank, a wildfire burned $90 \%$ of the study area. All 8 of the study plots that we had established between 1997 and 1999 were burned, including the 4 plots where we had intended to compare seed banks of native and exotic grassland. Because fire had consumed both types of plots, we decided that it was still possible to make the comparison. In interpreting our data, we focused on the following questions: What is the density of seeds in the soil and how does it compare between native and exotic grasslands? Are seed banks in exotic grasslands poor in species compared to seed banks in native grasslands? Which species have persistent seed banks? And which are transient in the soil?

\section{Study AREA}

Our study area was the Appleton-Whittell Research Ranch in northeastern Santa Cruz County, Arizona. This 3240-ha reserve is operated by the National Audubon Society. It has not been grazed by domestic livestock since 1969 (Bock and Bock 1986). The research ranch is located at $31^{\circ} 35^{\prime} \mathrm{N}$ and $110^{\circ} 30^{\prime} \mathrm{W}$ and lies between $1417 \mathrm{~m}$ and $1570 \mathrm{~m}$ above sea level.

Topography of the research ranch consists of nearly level mesas dissected by broad or narrow drainages. Grasslands occur on the mesa tops, and oak savannas are found in shallow drainages and on east- and north-facing slopes of major ravines. The grassland has been described as Madrean mixed-grass prairie (Bock and Bock 2000) and is dominated by $\mathrm{C}_{4}$ perennial bunchgrasses, primarily Bouteloua gracilis, B. curtipendula, and Eragrostis intermedia. (Unless otherwise noted, nomenclature follows McLaughlin et al. 2001.) Vegetation cover in this community is about $65 \%$ (McLaughlin and Bowers 2006). Stands dominated by the exotic grasses E. curvula and $E$. lehmanniana are confined mostly to mesa tops. Eragrostis curvula was seeded at the research ranch in 1949 (Audubon Research Ranch 2003) and has spread beyond the original plantings, although not as aggressively as E. lehmanniana (J. Bock personal communication; L. Kennedy personal communication). Oak savanna at the research ranch is typical Madrean evergreen woodland (Brown 1982) with an overstory of Quercus emoryi, Q. arizonica, and Q. oblongifolia. On 30 April 2002, the Ryan Fire swept across the research ranch, burning >2900 ha. Only a small portion of native grassland remained unburned, but no exotic grassland communities escaped the fire.

Precipitation was recorded at the research ranch in 26 years from 1968 to 2003. Average annual precipitation during this period was $430 \mathrm{~mm}$. At the nearest long-term weather station (Canelo, AZ, about $5 \mathrm{~km}$ distant), average annual precipitation from 1910 to 2003 was $460 \mathrm{~mm}$. Mean temperature in June, the hottest month, was $32.4^{\circ} \mathrm{C}$, and mean temperature in January, the coldest month, was $-3.3^{\circ} \mathrm{C}$ (WRCC 2004). About two-thirds of the annual precipitation falls in summer (July-September; Bock and Bock 1986). The winter rainy season is less well defined but generally lasts from November through February. Since 1998, Arizona has 
been in a major drought (McPhee et al. 2004). The 1st year of our seed bank study (2002) was the driest on record in many parts of the state (McPhee et al. 2004).

\section{Methods}

\section{Sampling Soil Seed Banks}

Between fall 1997 and spring 1999, we established four 0.1 -ha plots $(50 \times 20 \mathrm{~m})$ in unburned exotic grassland (plots 3 and 5) and unburned native grassland (plots 7 and 8). We monitored species richness on these plots from date of establishment to May 2001 (McLaughlin and Bowers 2006). Plots 3 and 5 were dominated by E. curvula, and plots 7 and 8 by mixtures of native species. All 4 plots were located on mesa tops where the soil type was White House gravelly loam. Elevation above mean sea level was $1460 \mathrm{~m}$ at plot $3,1480 \mathrm{~m}$ at plot 5 , $1515 \mathrm{~m}$ at plot 7 , and $1495 \mathrm{~m}$ at plot 8 . Because the 4 plots were similar in soil type, topography, and elevation, it seemed likely that differences in seed banks between the native and exotic community types could be ascribed to E. curvula rather than to physical environment. Within each plot, we randomly placed ten $1-\mathrm{m}^{2}$ quadrats $(0.5 \times 2.0 \mathrm{~m})$. Plots and quadrats were permanently marked with metal stakes. Shortly before we were scheduled to sample the soil seed banks, all 4 plots burned in the Ryan Fire. About 1 month after the fire, we established a 5th plot and a set of quadrats in the northwest corner of the research ranch where native grassland had not burned (plot 9). This additional plot provided supplementary information about seed persistence and seed bank composition. Because it was not a true control plot, we excluded it from statistical analyses.

To determine which species form persistent seed banks, samples should be taken when the germination season is over and shortly before new seeds disperse (Baskin and Baskin 1998). Any viable seeds in the soil at that point likely belong to the persistent seed bank. At our study site, winter and summer rains result in 2 flowering seasons and also 2 germination seasons. Seeds of spring-flowering species disperse by late May or June; summer- and autumn-flowering species retain seeds as late as October. We sampled seed banks of all 5 plots in June, August, and October 2002 and June 2003. On each sample date, we collected 2 randomly located soil samples next to every quadrat by pounding a $10 \times 10 \times 2-\mathrm{cm}$ metal frame into the ground and removing all soil within the frame to a depth of $2 \mathrm{~cm}$. We stored soil samples in labeled paper bags at room temperature.

\section{Seed Bank Size and Richness}

We determined quantity and identity of viable seeds in the soil samples through germination trials. This method might underestimate the total seed bank if many seeds remain dormant; on the other hand, the flotation method, which typically retrieves many nonviable seeds, can overestimate the total seed bank (Gross 1990). Because of space limitations, we ran trials consecutively, rather than simultaneously, as follows: June 2002 sample, germination trial June-July 2002; August 2002 sample, germination trial September-November 2002; October 2002 sample, germination trial January-March 2003; and June 2003 sample, germination trial August-October 2003. For each trial, the 2 soil samples for each quadrat were mixed, weighed, and divided in half. One half was set aside in case of greenhouse failure. The other half was sieved to remove rocks and other debris and then evenly sprinkled over moistened vermiculite in a plastic seedling tray $(32.5 \times 32.5 \times 7.5 \mathrm{~cm})$. There were 50 trays (5 plots $\times 10$ quadrats), each representing a sampling area of about $1 \mathrm{dm}^{2}$, for each germination trial. Seedling trays were kept in a greenhouse in Tucson, Arizona, and watered regularly. The greenhouse was cooled in summer and heated in winter but experienced considerable daily and seasonal temperature variation. Greenhouse temperatures, like those of the study site, were cool from November to March and warm from April to October. Daily, monthly, and seasonal variability in greenhouse temperatures helped ensure germination of a wide array of species; nevertheless, seeds of some species may have failed to germinate because of dormancy. Our seedling counts are therefore best regarded as a measure of the germinable seed bank rather than the total seed bank.

Once emergence began, we counted seedlings weekly for 5 to 8 weeks until no new seedlings emerged. We marked each new seedling with a toothpick and identified it as a monocotyledon or dicotyledon. As early as possible, we further identified seedlings to species; 
in the meantime, we assigned a unique descriptor to each morphologically distinct entity (e.g., grass \#1, rosette \#3). At the end of each trial, we transplanted representative unidentified seedlings to individual containers, which we kept in the greenhouse until seedlings could be identified.

We used seedling counts as a measure of the germinable seed bank on a given sample date; these counts included all seedlings that emerged in a given tray, whether identified to species or not. We expressed seed density for each plot as the average of ten $1-\mathrm{dm}^{2}$ samples (number of seeds $\cdot \mathrm{dm}^{-2}$ ) or as the sum of ten $1-\mathrm{dm}^{2}$ samples (number of seeds $\cdot \mathrm{m}^{-2}$ ). We used the number of morphologically distinct entities that emerged in each tray as a measure of species richness in the seed bank, again expressed for each plot as the average of ten $1-\mathrm{dm}^{2}$ samples (number of species $\cdot \mathrm{dm}^{-2}$ ) or as the total number of species found in ten $1-\mathrm{dm}^{2}$ samples (number of species $\cdot \mathrm{m}^{-2}$ ).

\section{Data Analysis}

For burned grassland, we used repeated measures ANOVA to examine effects of community type (exotic vs. native) and sample date on number of seeds $\cdot \mathrm{dm}^{-2}$ or number of species $\cdot \mathrm{dm}^{-2}$. Sample size for these 2 tests was 40 (4 plots $\times 10$ quadrats). Although we did not undertake a statistical comparison of burned and unburned native grassland, we calculated and reported seed density and species richness for both "treatments" as a matter of interest. Following Thompson and Grime (1979), we used temporal patterns of abundance (number of seeds $\cdot \mathrm{m}^{-2}$ ) to determine whether seeds of individual species were transient (present in seed bank $<1$ year) or persistent (present in seed bank $\geq 1$ year). If seeds of a species were found at every sample date when greenhouse temperatures were warm enough for germination, we considered the species to be persistent. If the seed bank of a species fell to 0 during its germination season, we considered that species to be transient (while acknowledging that some species may have been present only as dormant seeds). Finally, we categorized seedlings by functional group (exotic grasses, native grasses, annual herbs, and perennial herbs), then compared plots in terms of functional group composition. For this comparison, we averaged number of seeds $\cdot \mathrm{m}^{-2}$ over 4 sample dates.

\section{Results}

\section{Seed Density}

In burned exotic grassland plots, average seed density $( \pm 1 s)$ over 4 sample dates was $501 \pm 198.9$ seeds $\cdot \mathrm{m}^{-2}$ and $196 \pm 123.8$ seeds $\cdot \mathrm{m}^{-2}$, whereas burned native grassland plots averaged $591 \pm 243.1$ seeds $\cdot \mathrm{m}^{-2}$ and $784 \pm$ 334.9 seeds $\cdot \mathrm{m}^{-2}$. Averaged over 4 sample dates, seed density $( \pm 1 s)$ of unburned native grassland was $1158 \pm 250.7$ seeds $\cdot \mathrm{m}^{-2}$. In repeated measures ANOVA, seed banks in burned exotic grassland were significantly smaller than those in burned native grassland (Table 1). The effect of time within treatments was also significant (Table 1). Seed density in burned native grassland rose more or less steadily throughout the 13 months of sampling. In burned exotic grassland, seed density essentially leveled off after the 5th month (Fig. 1). The significant interaction between treatment (exotic vs. native) and time (Table 1) reflected, at least in part, the marked difference between native and exotic grassland in June 2003. One year after the fire, quadrats in native grassland averaged 1.3 to 5.4 times as many seeds $\cdot \mathrm{dm}^{-2}$ as those in exotic grassland. The unburned native plot experienced marked seasonal fluctuations as a result of seed dispersal and germination (Fig. 1). June peaks resulted from seed dispersal during the previous summer and autumn; August and October declines reflected germination during warm-season rains. Seed density in unburned native grassland was 16\% lower in June 2003 than in June 2002 (Fig. 1). The 12-month period starting in June 2002 was the 2 nd-driest on record at the research ranch, with only $263 \mathrm{~mm}$ of precipitation, about $60 \%$ of the long-term average. Severe drought likely reduced fecundity and survival in unburned native grassland, causing a substantial decline in seed density between June 2002 and June 2003.

\section{Species Richness}

Averaged across all 4 sample dates $( \pm 1 s)$, there were $12.0 \pm 3.4$ seeds $\cdot \mathrm{m}^{-2}$ and $11.06 \pm$ 2.5 seeds $\cdot \mathrm{m}^{-2}$ in burned exotic grassland plots, in contrast to $16.3 \pm 1.7 \mathrm{seeds} \cdot \mathrm{m}^{-2}$ and $19.5 \pm$ 1.0 seeds $\cdot \mathrm{m}^{-2}$ in burned native grassland plots. Richness of the seed bank in unburned native grassland was $21.8 \pm 3.0$ seeds $\cdot \mathrm{m}^{-2}$, also averaged across 4 sample dates. In repeated measures ANOVA, seed banks in burned exotic 
TABLE 1. Effects of community type (native or exotic grassland) and sampling date (June 2002, August 2002, October 2002, June 2003) on seed density (seeds $\cdot \mathrm{dm}^{-2}$ ) in burned grassland: results of repeated measures ANOVA.

\begin{tabular}{lrrrr}
\hline Source of variation & df & \multicolumn{1}{c}{ MS } & \multicolumn{1}{c}{$F$} & \multicolumn{1}{c}{$P$} \\
\hline Community type $(C)$ & 1 & 46002.306 & 25.37 & $<0.001$ \\
Error & 38 & 1813.156 & & \\
Sampling date (D) & 3 & 16334.356 & 16.80 & $<0.001$ \\
C $\times$ D & 3 & 3461.223 & 3.56 & 0.017 \\
Error & 114 & 972.070 & & \\
\hline
\end{tabular}

grassland contained significantly fewer species than those in burned native grassland (Table 2). Sample date had a significant effect on richness within treatments (Table 2, Fig. 2). Whereas species richness of burned native grassland fluctuated only modestly over time, species richness of burned exotic grassland underwent a substantial decline between June 2002 and October 2002, and recovered only slightly by June 2003 (Fig. 2). The interaction between treatment and time was not significant (Table 2). In unburned native grassland, species richness fluctuated around the summer germination season, with a high point at the beginning of the season in June and a low point at the end of the season in October (Fig. 2).

\section{Trends in Functional Groups}

The functional group composition of seed banks differed markedly between plots (Fig. 3). Annual and perennial herbs were much more numerous in native grassland (plots 7,8 , and 9) than in exotic grassland (plots 3 and 5). Native grasses appeared in modest quantities in native grassland and appeared in minute quantities in exotic grassland. Exotic grasses (mainly E. curvula var. conferta) dominated the seed bank of exotic grassland but were were virtually absent from native grassland.

\section{Trends in Individual Species}

Unfortunately, $21 \%$ of seedlings in the greenhouse died before they could be identified to species. Even so, we were able to examine temporal patterns of seed abundance for the most common species $\left(\geq 5\right.$ seeds $\cdot \mathrm{m}^{-2}$ on at least 1 sample date) and assess their persistence in the soil (Tables 3,4). As we will discuss, 20 species had persistent seed banks; the remainder were likely transient. Altogether, we identified 50 taxa to genus or species: 15

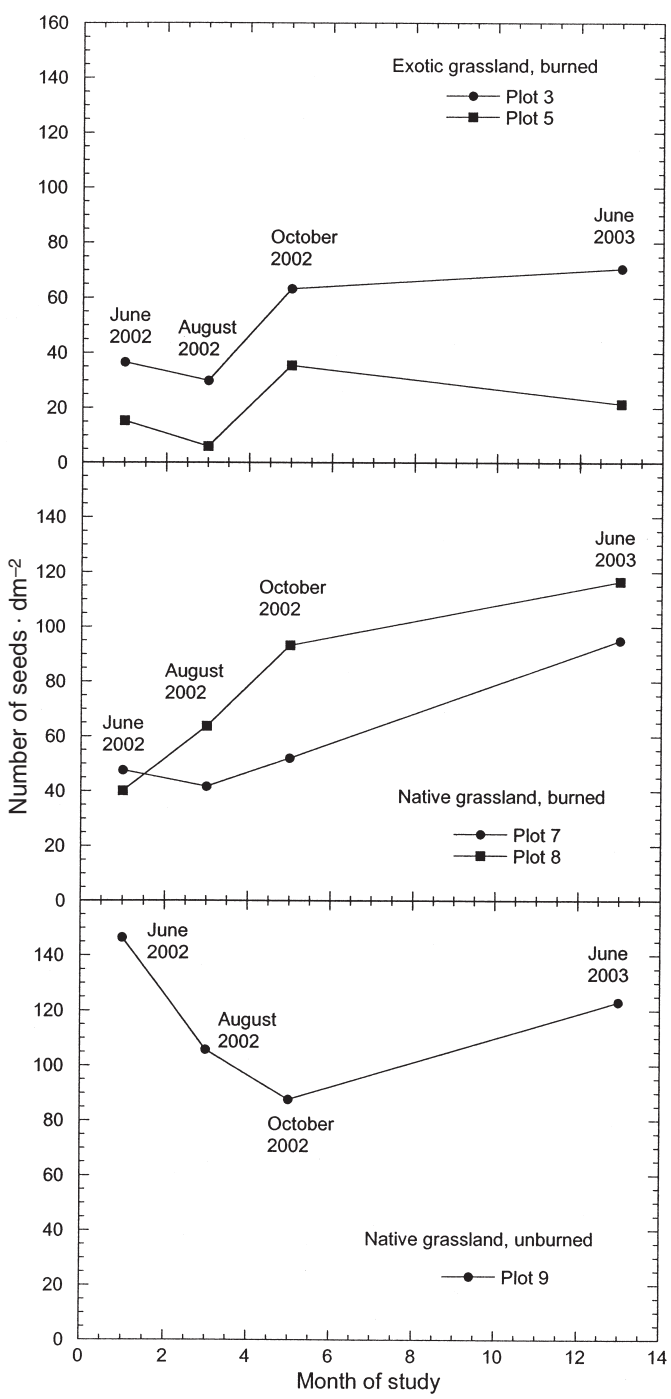

Fig. 1. Seed density (number of seeds $\cdot \mathrm{dm}^{-2}$ ) in soil seed banks on 4 sampling dates. Burned exotic grassland (2 plots), burned native grassland ( 2 plots), and unburned native grassland (1 plot) were sampled at the Appleton-Whittell Research Ranch, Arizona, in June 2002, August 2002, October 2002, and June 2003.

grasses and flat-sedges (Cyperaceae), 34 annual and perennial herbs, and 1 tree (Table 5).

\section{Discussion}

\section{Effect of Exotic Lovegrass} on Grassland Seed Banks

Without human intervention, it is notoriously difficult for native bunchgrasses to reoccupy dense stands of exotic lovegrasses (Bock 


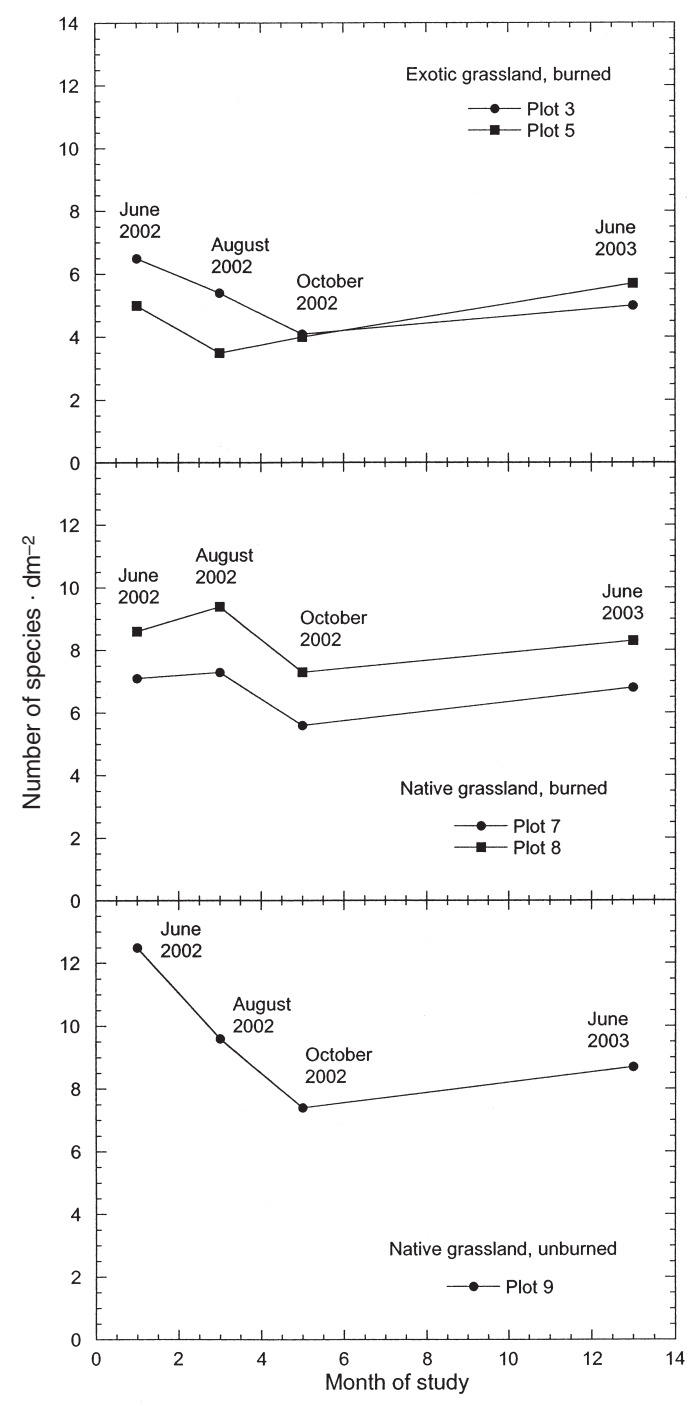

Fig. 2. Species richness (number of species $\cdot \mathrm{dm}^{-2}$ ) in soil seed banks on 4 sampling dates. Burned exotic grassland ( 2 plots), burned native grassland ( 2 plots), and unburned native grassland (1 plot) were sampled at the Appleton-Whittell Research Ranch, Arizona, in June 2002, August 2002, October 2002, and June 2003.

and Bock 1992, Biedenbender and Roundy 1996, Voigt et al. 1996); thus, acreage lost to these species is likely to remain that way indefinitely. The problem is especially acute in parks and preserves established for protection and restoration of native ecosystems. At the research ranch in southeastern Arizona, mesatop grassland has been distinctly altered by 50 years of dominance by E. curvula var. conferta, an exotic perennial grass. Among other changes,
TABLE 2. Effects of community type (native or exotic grassland) and sampling date (June 2002, August 2002, October 2002, June 2003) on species richness (species . $\mathrm{dm}^{-2}$ ) in burned grassland: results of repeated measures ANOVA.

\begin{tabular}{lrrcr}
\hline Source of variation & df & \multicolumn{1}{c}{ MS } & $F$ & $P$ \\
\hline Community type (C) & 1 & 280.900 & 45.422 & $<0.001$ \\
Error & 38 & 6.184 & & \\
Sampling date (D) & 3 & 18.167 & 6.468 & $<0.001$ \\
C $\times$ D & 3 & 2.809 & 2.528 & 0.061 \\
Error & 114 & 2.809 & & \\
\hline
\end{tabular}

plant species richness at small spatial scales has declined dramatically, perhaps as a consequence of competition or allelopathy (McLaughlin and Bowers 2006). We initially hypothesized that loss of species over the past 5 decades should have greatly reduced the seed bank, and our results showed that this was indeed the case. We found that burned exotic grassland had a smaller reserve of seeds in the soil than burned native grassland (Fig. 1), that this reserve was poor in species compared to native grassland (Fig. 2), and that its main component was exotic grasses (Fig. 3), particularly E. curvula var. conferta. In contrast to most native species at our study site, E. curvula has a persistent seed bank (see below). Restoration efforts in natural preserves typically involve 2 somewhat independent processes: elimination of exotics and reestablishment of natives. At the research ranch, it appears that even if E. curvula can be eliminated, the seed bank in exotic grassland is so depleted of natives that the plant community is not likely to revert to its original status without substantial intervention. Other researchers have come to similar conclusions about Great Basin shrubsteppe (Hassan and West 1986, Humphrey and Schupp 2001) and South African fynbos (Holmes 2002).

\section{Longevity of Perennial Grass Seeds}

Native perennial grasses in our region germinate during the summer rainy season. With few exceptions, seeds of these species do not persist between years (Major and Pyott 1966, Rabinowitz 1981, Hassan and West 1986, Coffin and Lauenroth 1989, Kinucan and Smeins 1992) or persist only in small numbers (O’SheaStone 1988). Exceptions include Eragrostis intermedia (O'Shea-Stone 1988), Hilaria belangeri (Kinucan and Smeins 1992), and Sporobolus 


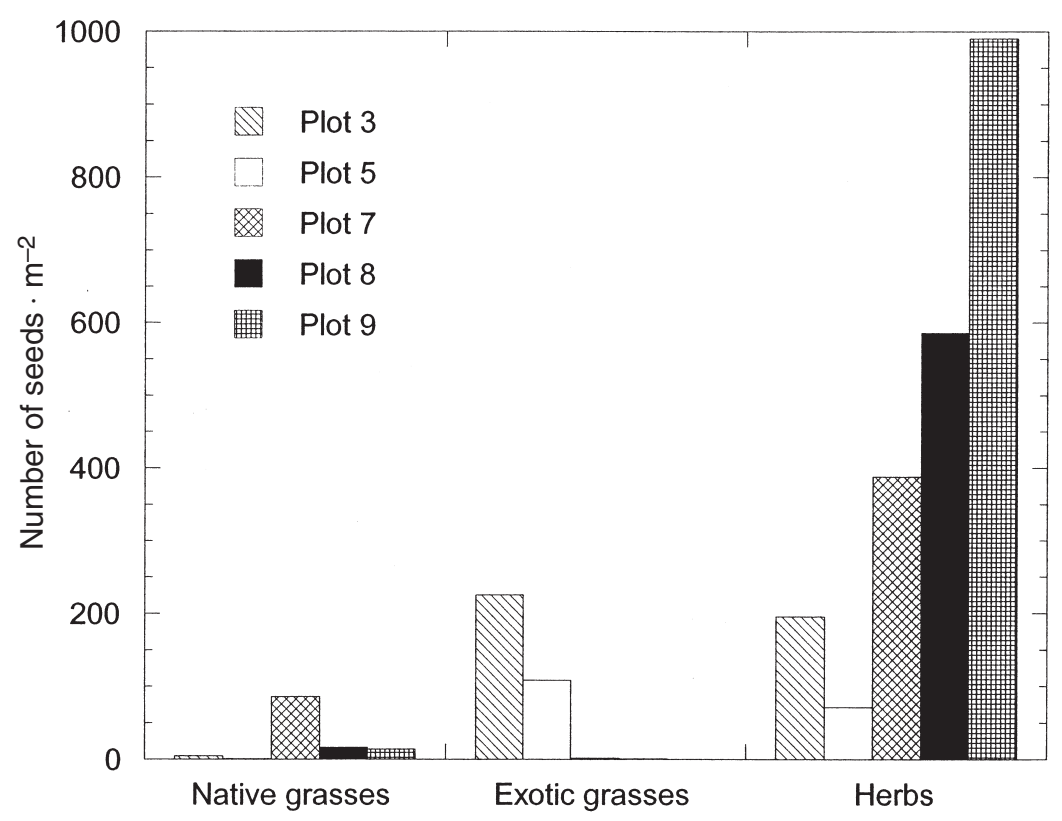

Fig. 3. Seed density (number of seeds $\cdot \mathrm{m}^{-2}$ ) in 3 functional groups on 5 plots: burned exotic grassland (Plots 3 and 5 ), burned native grassland (Plots 7 and 8), and unburned native grassland (Plot 9). Bars represent average for 4 sampling dates (June 2002, August 2002, October 2002, and June 2003) at the Appleton-Whittell Research Ranch, Arizona.

cryptandrus (Coffin and Lauenroth 1989). In our study, Eragrostis intermedia carried some seeds through the summer germination period and was likely persistent, assuming that its absence from the October sample can be explained by cool greenhouse temperatures (Tables 3, 4). Abundance of the exotic perennial grass E. curvula var. conferta dropped to a low level during the summer germination season, suggesting that its seed bank, although persistent, was small (Table 3 ). Because E. curvula seeds are persistent, eradication efforts will need to target seedlings for at least 1 year after adults have been eliminated (Biedenbender and Roundy 1996). A small number of unidentified grass seedlings emerged from the June 2002 sample, but other than E. curvula and E. intermedia, no perennial grasses emerged from the August 2002 sample. Greenhouse temperatures should have been warm enough for germination of grass seeds in the August sample, so it seems likely that seeds of most perennial grasses did not persist from June to August. Our results agree with a field study in which summer rain that germinated virtually all native grass seeds did not germinate all exotic lovegrass seeds (Abbott and Roundy 2003); thus, sufficient rain exhausted the seed bank of native perennial grasses but not that of exotic lovegrass (Abbott and Roundy 2003).

\section{Longevity of Perennial Herb Seeds}

Among perennial herbs, Astragalus nothoxys, Gnaphalium canescens, Erigeron spp., and Verbena gracilis were present at every sample date and can be considered persistent (Tables 3, 4). An earlier study (Kinucan and Smeins 1992) also found that Verbena gracilis has a persistent seed bank. Portulaca suffrutescens and Guilleminea densa were absent in October, when temperatures were perhaps too low for germination, but present at all other sample dates (albeit in low numbers at times); these species probably had persistent seeds. Although not previously known from any plot, Dalea albiflora was detected in soil samples (Table 5); such behavior is indicative of a persistent seed bank (Thompson et al. 1993). Seeds of Lotus greenei were found only in June (Table 4), probably indicating that this perennial herb is transient in the seed bank; alternatively, seeds may have been present in our samples in other months, but dormant and therefore not detected as emergent seedlings. 


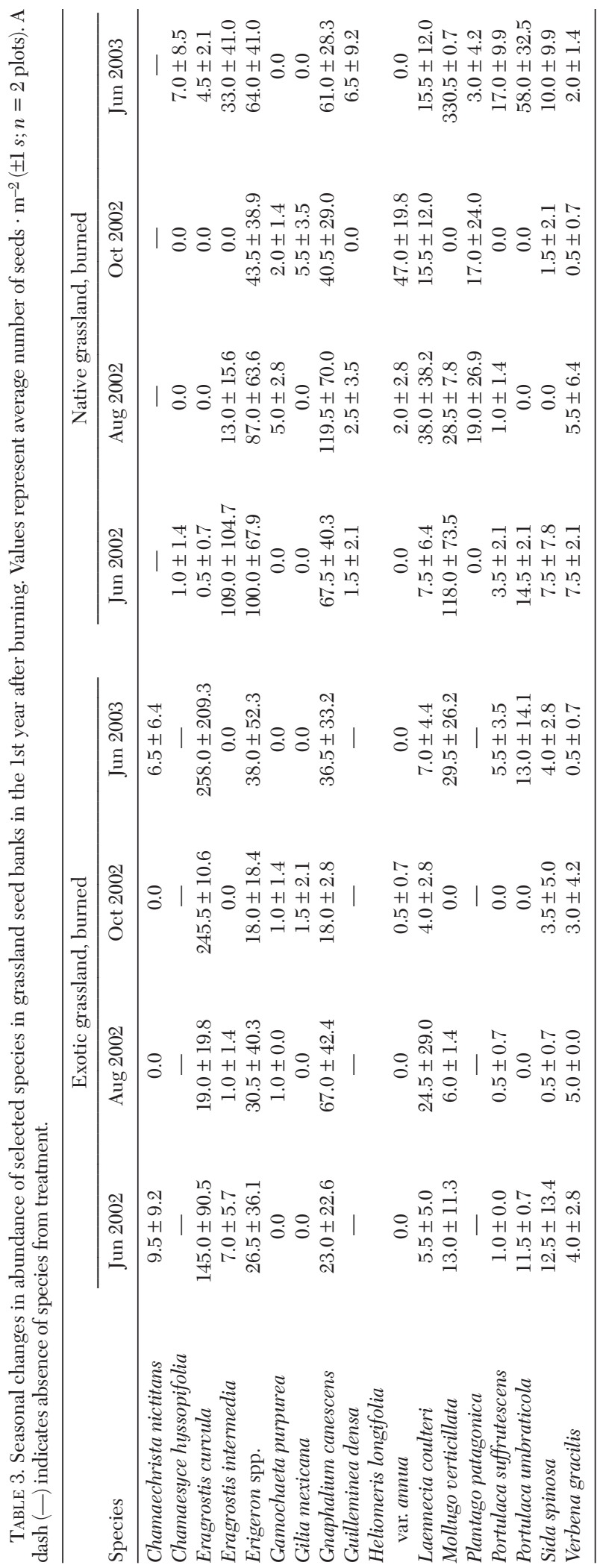


TABLE 4. Seasonal changes in abundance of selected species in the seed bank of unburned native grassland. Values represent number of seeds $\cdot \mathrm{m}^{-2}(n=1$ plot $)$.

\begin{tabular}{|c|c|c|c|c|}
\hline Species & Jun 2002 & Aug 2002 & Oct 2002 & Jun 2003 \\
\hline Astragalus nothoxys & 45 & 8 & 5 & 11 \\
\hline Chamaesyce hyssopifolia & 16 & 1 & 0 & 17 \\
\hline Cyperus squarrosus & 10 & 0 & 0 & 1 \\
\hline Diodia teres & 105 & 1 & 0 & 181 \\
\hline Eragrostis intermedia & 24 & 8 & 0 & 7 \\
\hline Erigeron spp. & 396 & 325 & 193 & 262 \\
\hline Gamochaeta purpurea & 0 & 2 & 5 & 0 \\
\hline Gilia mexicana & 0 & 0 & 97 & 0 \\
\hline Gnaphalium canescens & 50 & 197 & 61 & 68 \\
\hline Laennecia coulteri & 2 & 21 & 2 & 11 \\
\hline Lipocarpha micrantha & 46 & 0 & 0 & 10 \\
\hline Lotus greenei & 8 & 0 & 0 & 5 \\
\hline Machaeranthera gracilis & 0 & 16 & 12 & 1 \\
\hline Mollugo verticillata & 655 & 8 & 0 & 275 \\
\hline Nuttallanthus texanus & 0 & 6 & 9 & 0 \\
\hline Plantago patagonica & 0 & 50 & 31 & 6 \\
\hline Portulaca suffrutescens & 46 & 3 & 0 & 25 \\
\hline Portulaca umbraticola & 34 & 0 & 0 & 15 \\
\hline Sida spinosa & 13 & 0 & 1 & 2 \\
\hline Vulpia octoflora & 0 & 6 & 0 & 0 \\
\hline
\end{tabular}

Longevity of Seeds of Woody Plants

Of the few woody species known from plot floras (Baccharis pteronioides, Isocoma tenuisecta, Mimosa aculeaticarpa, M. dysocarpa; McLaughlin and Bowers unpublished data), none was detected in the seed bank. Mimosa seeds have hard coats and, under ordinary circumstances, should be long lived in the soil. The 2001 seed crop may have been destroyed by fire or eaten by granivores; in 2002, plants on our plots were too badly burned to reproduce. Unexpectedly, a single seedling of Juniperus deppeana emerged from a plot where the species was previously unknown (Table 5). Some species of Juniperus maintain small persistent seed banks (Clemente et al. 2004, Van Auken et al. 2004), whereas others do not (Tunnell et al. 2004); our evidence is too scanty for a firm conclusion about J. deppeana.

\section{Longevity of Seeds of Annual Plants}

Winter annuals in our region germinate during late autumn and winter, and flower in spring. Summer annuals germinate and flower during the summer rainy season. Seed banks of winter and summer annuals showed contrasting patterns for the most part. Many summer annuals detected in our samples were present in the June seed bank but were virtu- ally or entirely absent from the August seed bank and can therefore be regarded as transient. They included Chamaechrista nictitans, Chamaesyce hyssopifolia, Diodia teres, Portulaca umbraticola, and Sida spinosa (Tables 3, 4). We found certain other summer annuals (Acalypha neomexicana, Eriochloa acuminata, Ipomoea costellata, and Panicum hirticaule) in such small numbers ( 1 or 2 seeds in 200 samples) that we assume they were transient as well. We detected these latter summer annuals on the unburned plot as well, so their low abundance cannot be ascribed to fire. It is, of course, possible that these species were present in our samples but were largely dormant.

In contrast to seeds of many summer annuals, those of winter annuals were probably long lived in the soil. These included Gamochaeta purpurea (L.) Cabrera, Gilia mexicana, Nuttallanthus texanus (Scheele) D.A. Sutton, and Plantago patagonica. All 4 were found in the October sample, and some were found in small numbers in other months (Tables 3, 4). Another winter annual, Vulpia octoflora, was detected in small quantities in August (Table 4). Plantago patagonica and Vulpia octoflora are known to have persistent seed banks (Pake and Venable 1996; see also Coffin and Lauenroth 1989), just like most winter annuals in our region that have been studied (Venable and Pake 1999). Had we sampled in February 2003 
TABLE 5. Species detected in grassland seed banks at the Appleton-Whittell Research Ranch, Arizona. Distribution of species in various treatments is as follows: burned exotic grassland, plots 3 and 5 ; burned native grassland, plots 7 and 8 ; unburned native grassland, plot 9 . An asterisk (*) denotes species not previously recorded for the floras of plots $3,5,7$, or 8 (McLaughlin and Bowers unpublished data). There was no previous flora for plot 9 . All species are native unless otherwise noted.

\begin{tabular}{|c|c|c|c|c|c|}
\hline \multirow[b]{2}{*}{ Species } & \multicolumn{5}{|c|}{ Plot number } \\
\hline & 3 & 5 & 7 & 8 & 9 \\
\hline \multicolumn{6}{|l|}{ PERENNIAL GRASSES AND FLAT-SEDGES } \\
\hline Aristida divaricata & & & $\mathrm{X}$ & $\mathrm{X}$ & \\
\hline Bouteloua gracilis & & & & & $\mathrm{X}$ \\
\hline Cyperus sphaerolepis & & & $\mathrm{X}$ & & $\mathrm{X}$ \\
\hline Eragrostis curvula var. conferta (exotic) & $\mathrm{X}$ & $\mathrm{X}$ & $\mathrm{X}$ & $\mathrm{X}$ & \\
\hline Eragrostis intermedia & $\mathrm{X}$ & $\mathrm{X}^{*}$ & $\mathrm{X}$ & $\mathrm{X}$ & $\mathrm{X}$ \\
\hline Eragrostis lehmanniana & $\mathrm{X}$ & & $\mathrm{X}$ & $\mathrm{X}$ & $\mathrm{X}$ \\
\hline Lycurus setosus & & & $\mathrm{X}$ & & \\
\hline \multicolumn{6}{|l|}{ ANNUAL GRASSES AND FLAT-SEDGES } \\
\hline Aristida adscensionis & & & $\mathrm{X}^{*}$ & & \\
\hline Brachiaria arizonica & & & & & $\mathrm{X}$ \\
\hline Cyperus squarrosus & & & & $X^{*}$ & $\mathrm{x}$ \\
\hline Eragrostis pectinacea & $X^{*}$ & $\mathrm{X}^{*}$ & $\mathrm{x}$ & $\mathrm{X}$ & $\mathrm{X}$ \\
\hline Eriochloa acuminata & & & & $\mathrm{X}^{*}$ & \\
\hline Lipocarpha micrantha & & & $\mathrm{X}^{*}$ & $X^{*}$ & $\mathrm{X}$ \\
\hline Panicum hirticaule & & & & $\mathrm{X}$ & $\mathrm{X}$ \\
\hline Vulpia octoflora & & & $\mathrm{x}$ & & $\mathrm{x}$ \\
\hline \multicolumn{6}{|l|}{ PERENNIAL AND BIENNIAL HERBS } \\
\hline Astragalus nothoxys & & & & $\mathrm{X}$ & $\mathrm{X}$ \\
\hline Convolvulus equitans & & & $\mathrm{x}$ & & \\
\hline Dalea albiflora & $\mathrm{X}^{*}$ & & & & \\
\hline Dyschoriste decumbens & & $\mathrm{X}$ & $\mathrm{X}$ & & \\
\hline Erigeron flagellaris & & & $\mathrm{X}$ & & \\
\hline Erigeron spp. & $\mathrm{X}$ & $\mathrm{X}$ & $\mathrm{X}$ & $\mathrm{X}$ & $\mathrm{X}$ \\
\hline Evolvulus sp. & $\mathrm{X}$ & & $\mathrm{x}$ & $\mathrm{X}$ & $\mathrm{X}$ \\
\hline Gaura sp. & & & & $\mathrm{X}$ & \\
\hline Gnaphalium canescens & $\mathrm{x}$ & $\mathrm{X}$ & $\mathrm{X}^{*}$ & $\mathrm{X}^{*}$ & $\mathrm{x}$ \\
\hline Guilleminea densa & & & & $\mathrm{X}$ & $\mathrm{X}$ \\
\hline Lotus greenei & & & & $\mathrm{X}$ & $\mathrm{X}$ \\
\hline Machaeranthera pinnatifida & & & & $\mathrm{X}$ & \\
\hline Portulaca suffrutescens & $\mathrm{X}$ & $\mathrm{X}$ & $\mathrm{X}$ & $\mathrm{X}$ & $\mathrm{X}$ \\
\hline Sida abutifolia & $\mathrm{X}$ & $\mathrm{X}$ & $\mathrm{X}$ & $\mathrm{X}$ & \\
\hline Sida neomexicana & & & & $\mathrm{X}$ & \\
\hline Talinum aurantiacum & & & $\mathrm{x}$ & & \\
\hline Verbena gracilis & $\mathrm{X}$ & $\mathrm{x}$ & $\mathrm{X}$ & $\mathrm{X}$ & $\mathrm{X}$ \\
\hline \multicolumn{6}{|l|}{ ANNUAL HERBS } \\
\hline Acalypha neomexicana & & & & & $\mathrm{X}$ \\
\hline Chamaecrista nictitans & $\mathrm{X}$ & $\mathrm{X}$ & & & $\mathrm{X}$ \\
\hline Chamaesyce hyssopifolia & & & $\mathrm{X}$ & $\mathrm{X}$ & $\mathrm{X}$ \\
\hline \multicolumn{6}{|l|}{ Descurainia pinnata } \\
\hline Diodia teres & $\mathrm{X}$ & & & & $\mathrm{X}$ \\
\hline Gamochaeta purpurea & $\mathrm{X}$ & $\mathrm{X}$ & $\mathrm{X}$ & $\mathrm{X}$ & $\mathrm{X}$ \\
\hline Gilia mexicana & & $\mathrm{X}$ & $\mathrm{x}$ & $\mathrm{X}$ & $\mathrm{X}$ \\
\hline Heliomeris longifolia var. аппиа & $\mathrm{X}$ & & $\mathrm{X}^{*}$ & $\mathrm{X}^{*}$ & $\mathrm{X}$ \\
\hline Ipomoea costellata & & $\mathrm{X}$ & & & $\mathrm{X}$ \\
\hline Laennecia coulteri & $\mathrm{X}^{*}$ & $X^{*}$ & $\mathrm{X}^{*}$ & $X^{*}$ & $\mathrm{X}$ \\
\hline Machaeranthera gracilis & & & $X^{*}$ & $X^{*}$ & $\mathrm{X}$ \\
\hline Mollugo verticillata (exotic) & $\mathrm{X}$ & $\mathrm{X}$ & $\mathrm{x}$ & $\mathrm{X}$ & $\mathrm{x}$ \\
\hline Nuttallanthus texanus & & & $\mathrm{X}$ & $\mathrm{X}$ & $\mathrm{X}$ \\
\hline Pectis prostrata & & & & $\mathrm{X}^{*}$ & $\mathrm{X}$ \\
\hline Plantago patagonica & & & & $\mathrm{X}$ & $\mathrm{X}$ \\
\hline Portulaca umbraticola & $\mathrm{X}$ & $\mathrm{X}$ & $\mathrm{X}$ & $\mathrm{X}$ & $\mathrm{X}$ \\
\hline Sida spinosa & $\mathrm{X}$ & $\mathrm{X}$ & $\mathrm{X}$ & $\mathrm{X}$ & $\mathrm{X}$ \\
\hline \multicolumn{6}{|l|}{ TREES AND SHRUbS } \\
\hline Juniperus deppeana & & $\mathrm{X}^{*}$ & & & \\
\hline
\end{tabular}


and found seeds of Gamochaeta, Gilia, Nuttallanthus, Plantago, and Vulpia, we could conclude with certainty that all these winter annuals have persistent seed banks; as it is, we can say only that their persistence in the soil is very likely.

Seed bank dynamics of summer and winter annuals at our study site may be adapted to regional precipitation patterns. Summer annuals in southeastern Arizona typically germinate in July and August and complete their life cycle by September or October. The convective storms that trigger their germination are temporally reliable but spatially variable. Winter annuals germinate between October and March and disperse seeds by April or May. In southeastern Arizona, winter rains arrive as frontal systems that cover a broad area but are temporally variable. Freas and Kemp (1983) speculated that in keeping with these precipitation patterns, the germination fraction should be large for summer annuals, which experience suitable if scattered conditions for germination every year, and small for winter annuals, which face a much higher risk of extinction. If their hypothesis is correct, one would expect summer annuals to have transient seed banks and winter annuals to have persistent seed banks. Our results support this idea.

Not all summer annuals had transient seed banks, however. Exceptions to the general pattern included Mollugo verticillata, which maintained a sizeable seed bank (Tables 3, 4), and Eragrostis pectinacea, which germinated in small numbers after every sample date. Note also that 4 summer annuals (Aristida adscensionis, Cyperus squarrosus, Lipocarpha micrantha (Vahl) G. Tucker, and Pectis prostrata) germinated on plots where they were previously unknown (Table 5). Although such behavior is considered to be a strong indication of persistent seed banks (Thompson et al. 1993), we found only a single seed of $A$. adscensionis, scanty evidence on which to base a conclusion about persistence, and $P$. prostrata appeared only in the final sample of the study, which suggests recent immigration. We do accept the implication that seeds of L. micrantha and C. squarrosus persist in the soil; moreover, $C$. squarrosus is known to have a persistent seed bank (Kinucan and Smeins 1992).

Finally, several species cannot be classified as winter or summer annuals. Laennecia coulteri, which blooms from late spring to autumn
(Kearney and Peebles 1969), emerged in substantial numbers in all months (Tables 3, 4) and clearly had a persistent seed bank. This species was not known from the flora of any plot before the Ryan Fire (McLaughlin and Bowers unpublished data) but was afterward found in the seed banks of all plots (Table 5). Machaeranthera gracilis, which blooms from early spring to autumn (Kearney and Peebles 1969), maintained a small seed bank during the germination season (Table 4) and probably had persistent seeds. Similarly, Heliomeris longifolia var. апnиa, a summer and autumn bloomer, was not previously known from any plot (Table 5) and was doubtless persistent. Soil samples taken at the research ranch in 1986 and 1987 demonstrated that Heterotheca subaxillaris, another biseasonally flowering annual or biennial (Kearney and Peebles 1969), also has a persistent seed bank (O'Shea-Stone 1988). Laennecia, Machaeranthera, and Heterotheca commonly colonize disturbed sites such as roadsides. Their persistent seed banks allow seeds to remain in the soil until disturbance creates appropriate habitat.

\section{The Role of Seed Banks in Southeastern Arizona Grasslands}

Our results confirm earlier findings that North American grasslands do not depend on persistent seed banks for continuity (e.g., Major and Pyott 1966, O'Shea-Stone 1988, Coffin and Lauenroth 1989, Kinucan and Smeins 1992). Of 111 species found growing on plots 3, 5, 7, and 8 between 1997 and 2001 (Bowers and McLaughlin unpublished data), only 50 were represented as identifiable taxa in the seed bank (Table 5). As was the case in north central New Mexico (Henderson et al. 1988), most species were already known from their respective communities (Table 5). Conversely, most species known from our plot floras were not detected as seeds in our soil samples. Some of these absent species were truly transient in the soil. Others died before we could identify them as something other than morphologically distinct entities. Still other species doubtless would have been detected had their seeds not been destroyed by wildfire. Despite these unknown quantities, it appears that the majority of species in the plot floras lacked persistent seed banks. Our site is not one where many species remain dormant in the soil for years 
waiting for severe, unpredictable disturbance of soil or vegetation to open up gaps and provide light (e.g., Thompson and Grime 1979). Rather, bare ground is readily available, and frequent fires and droughts open up the community still further. Transient seeds are well suited to such conditions. On the other hand, the preponderance of transient species in the seed bank means that native seeds must be sown after exotic grasses have been eradicated. Otherwise, recovery of native grassland will be long delayed. Given interannual variability in summer rain, it might be necessary to sow native seeds twice per summer for several consecutive years to achieve successful establishment (Biedenbender and Roundy 1996).

\section{ACKNOWLEDGments}

We thank the Arizona Game and Fish Department for financial support, K. Pokorny and L. Kennedy for assistance in the field, B. Branan for permission to work at the Appleton-Whitell Research Ranch, and T. Bean and L. Kennedy for reading and commenting on the manuscript. L. Kennedy provided recent precipitation data for the research ranch.

\section{Literature Cited}

Aввотt, L.B., ANd B.A. Roundy. 2003. Available water influences field germination and recruitment of seeded grasses. Journal of Range Management 56:56-64.

Audubon Research Ranch. 2003. Invasive species. Accessed 1 September 2004. Available from: http:// www.audubonresearchranch.org

BAHRE, C.J. 1991. A legacy of change: historic human impact on vegetation of the Arizona borderlands. University of Arizona Press, Tucson. 231 pp.

Baskin, C.C., AND J.M. Baskin. 1998. Seeds: ecology, biogeography, and evolution of dormancy and germination. Academic Press, San Diego, CA. 666 pp.

Biedenbender, S.H., And B.A. Roundy. 1996. Establishment of native semidesert grasses into existing stands of Eragrostis lehmanniana in southeastern Arizona. Restoration Ecology 4:155-162.

Bock, C.E., AND J.H. BocK. 2000. The view from Bald Hill: thirty years in an Arizona grassland. University of California Press, Berkeley. 197 pp.

Bock, C.E., J.H. Bock, K.L. Jepson, And J.C. ORTEga. 1986. Ecological effects of planting African lovegrasses in Arizona. National Geographic Research 2:456-463.

Bock, J.H., AND C.E. Bock. 1986. The Appleton-Whittell Research Ranch Sanctuary of the National Audubon Society. Desert Plants 8:3-14.

1992. Vegetation responses to wildfire in native vs. exotic Arizona grassland. Journal of Vegetation Science 3:439-446.
BRown, D.E. 1982. Madrean evergreen woodland. Desert Plants 4:59-65.

Brown, J.H., J.J. Grover, D.W. Davidson, AND G.A. LieBERMAN. 1975. A preliminary study of seed predation in desert and montane habitats. Ecology 56: 987-992.

Burcham, L.T. 1957. California rangeland: an historicecological study of the range resource of California. Division of Forestry, Department of Natural Resources, Sacramento, CA.

Clemente, A.S., F.C. Rego, and O. Correia. 2004. Padroes de sobrevivencia de sementes em grupos functionais de resposta ao fogo. Revista de Biologia (Lisbon) 22: $123-132$.

Coffin, D.P., And W.K. Lauenroth. 1989. Spatial and temporal variation in the seed bank of a semiarid grassland. American Journal of Botany 76:53-58.

Cox, J.R., M.H. Martin-R, F.A. Ibarra-F, J.H. Fourie, N.F.G. Rethman, and D.G. Wilcox. 1988. The influence of climate and soils on the distribution of four African grasses. Journal of Range Management 41: 127-139.

Crider, F.J. 1945. Three introduced lovegrasses for soil conservation. USDA Circular 730, Washington, DC.

Freas, K.E., AND P.R. Kemp. 1983. Some relationships between environmental reliability and seed dormancy in desert annual plants. Journal of Ecology 71:211217.

Gross, K.L. 1990. A comparison of methods for estimating seed numbers in the soil. Journal of Ecology 78:1079-1093.

Hassan, M.A., and N.E. West. 1986. Dynamics of soil seed pools in burned and unburned sagebrush semideserts. Ecology 67:269-272.

Henderson, C.B., K.E. Petersen, and R.A. Redak. 1988. Spatial and temporal patterns in the seed bank and vegetation of a desert grassland community. Journal of Ecology 76:717-728.

Holmes, P.M. 2002. Depth distribution and composition of seed-banks in alien-invaded and uninvaded fynbos vegetation. Austral Ecology 27:110-120.

Humphrey, L.D., AND E.W. Schupp. 2001. Seed banks of Bromus tectorum-dominated communities in the Great Basin. Western North American Naturalist 61:85-92.

Kearney, T.H., and R.H. Peebles. 1969. Arizona flora. 2nd edition with supplement by J.T. Howell, E. McClintock, et al. University of California Press, Berkeley. 1085 pp.

KinuCAN, R.J., AND F.E. Smeins. 1992. Soil seed bank of a semiarid Texas grassland under three long-term (36 years) grazing regimes. American Midland Naturalist 128:11-21.

Major, J., AND W.T. PyotT. 1966. Buried, viable seeds in two California bunchgrass sites and their bearing on the definition of a flora. Vegetatio 13:253-282.

McLaughlin, S.P., AND J.E. Bowers. 2006. Plant species richness at different scales in native and exotic grasslands in southeastern Arizona. Western North American Naturalist 66:209-221.

McLaughlin, S.P., E.L. Geiger, and J.E. Bowers. 2001. Flora of the Appleton-Whittell Research Ranch, northeastern Santa Cruz County, Arizona. Journal of the Arizona-Nevada Academy of Science 33:113-131.

McPhee, J., A. Comrie, and G. Garfin. 2004. Drought and climate in Arizona: top ten questions and answers. 
Climate Assessment Project for the Southwest (CLIMAS), Institute for the Study of Planet Earth, University of Arizona, Tucson.

McPherson, G.R., and J.F. Weltzin. 2000. Disturbance and climate change in United States/Mexico borderland plant communities: a state-of-the-knowledge review. General Technical Report RMRS-GTR-50, USDA Forest Service, Fort Collins, CO.

O'Connor, T.G., And G.A. PICKetT. 1992. The influence of grazing on seed production and seed banks of some African savanna grasslands. Journal of Applied Ecology 29:247-260.

O'Shea-Stone, M. 1988. The seed bank in a semidesert grassland of southeastern Arizona and its relationship to the seed rain and vegetation. Master's thesis, University of Colorado, Boulder.

PaKe, C.E., AND D.L. Venable. 1996. Seed banks in desert annuals: implications for persistence and coexistence in variable environments. Ecology 77:1427-1435.

Pulliam, H.R., AND M.R. BRAND. 1975. The production and utilization of seeds in plains grassland of southeastern Arizona. Ecology 56:1158-1166.

RabinowitZ, D. 1981. Buried viable seeds in a North American tall-grass prairie: the resemblance of their abundance and composition to dispersing seeds. Oikos 36:191-195.

Thompson, K., J.P. BakKer, And R.M. BeKker. 1997. The soil seed banks of north west Europe: methodology, density and longevity. Cambridge University Press, Cambridge, U.K. 276 pp.

Thompson, K., S.R. Band, And J.G. Hodgson. 1993. Seed size and shape predict persistence in soil. Functional Ecology 7:236-241.
Thompson, K., AND J.P. GRImE. 1979. Seasonal variation in the seed banks of herbaceous species in ten contrasting habitats. Journal of Ecology 67:893-921.

Tunnell, S.J., J. Stubbendieck, J. Huddle, And J. BrolLIER. 2004. Seed dynamics of eastern redcedar in the mixed-grass prairie. Great Plains Research 14: 129-142.

Turner, R.M., R.H. Webb, J.E. Bowers, and J.R. HastINGS. 2003. The changing mile revisited: an ecological study of vegetation change with time in the lower mile of an arid and semiarid region. University of Arizona Press, Tucson. 334 pp.

Van Auken, O.W., J.T. Jackson, and P.N. Jurena. 2004. Survival and growth of Juniperus seedlings in Juniperus woodlands. Plant Ecology 175:245-257.

Venable, D.L., And C.E. Pake. 1999. Pages 115-142 in R.R. Robichaux, editor, Population ecology of Sonoran Desert annual plants. University of Arizona Press, Tucson.

Voigt, P.W., C.R. Tischler, and M.M. Poverene. 1996. Seed dormancy and its alleviation in lovegrass hybrids. Crop Science 36:1699-1705.

WEAVER, L.C., AND G.L. JoRDan. 1986. Effects of selected seed treatment of germination rates of five range plants. Journal of Range Management 38:415-418.

[WRCC] Western Regional Climate Center. 2004. Arizona climate summaries, Western Regional Climate Center. Accessed 1 September 2004. Available from: http://www.wrcc.dri.edu

Received 30 December 2005 Accepted 3 November 2006 